\title{
Neurogenin-1 Overexpression Increases the Therapeutic Effects of Mesenchymal Stem Cells through Enhanced Engraftment in an Ischemic Rat Brain
}

\author{
Gyu-Hee Kim ${ }^{1,2, *}$, Marasini Subash ${ }^{1,2, *}$, Jeong Seon Yoon ${ }^{1}$, Darong Jo ${ }^{2,3}$, \\ Jihun Han ${ }^{1,2}$, Ji Man Hong ${ }^{2,4}$, Sung-Soo Kim ${ }^{1}$, Haeyoung Suh-Kim ${ }^{1,2,3}$ \\ ${ }^{1}$ Department of Anatomy, Ajou University School of Medicine, Suwon, Korea \\ ${ }^{2}$ Department of Biomedical Sciences, Ajou Graduate School, Suwon, Korea \\ ${ }^{3}$ Research Center CelleBrain Ltd., Jeonju, Korea \\ ${ }^{4}$ Department of Neurology, Ajou University School of Medicine, Suwon, Korea
}

Background and Objectives: Stem cell therapy is a promising strategy for treating neurological diseases but its effectiveness is influenced by the route of administration and the characteristics of the stem cells. We determined whether neural induction of mesenchymal stem cells (MSCs) was beneficial when the cells were delivered intra-arterially through the carotid artery.

Methods and Results: MSCs were neurally induced using a retroviral vector expressing the neurogenic transcription factor neurogenin-1 (Ngn1). The LacZ gene encoding bacterial $\beta$-galactosidase was used as a control. Ischemic stroke was induced by transluminal occlusion of the middle cerebral artery and 3 days later the MSCs were delivered intra-arterially through the internal carotid artery. Magnetic resonance imaging analysis indicated that compared to MSCs expressing LacZ (MSCs/LacZ), MSCs expressing Ngn1 (MSCs/Ngn1) exhibited increased recruitment to the ischemic region and populated this area for a longer duration. Immunohistochemical analysis indicated that compared to MSCs/LacZ, MSCs/Ngnl more effectively alleviated neurological dysfunction by blocking secondary damage associated with neuronal cell death and brain inflammation. Microarray and real-time PCR analysis indicated that MSCs/Ngn1 exhibited increased expression of chemotactic cytokine receptors, adherence to endothelial cells, and migration ability. Conclusions: Neural induction with Ngnl increases the homing ability of MSCs, enhancing their engraftment efficiency in the ischemic rat brain. Intra-arterial delivery of neurally induced MSCs/Ngn1 3 days after ischemic injury blocks neuronal cell death and inflammation, and improves functional recovery. Thus, intra-arterial administration of stem cells with neural properties may be a novel therapy for the treatment of ischemic stroke.

Keywords: Mesenchymal stem cell, Neurogenin-1, Neural induction, Intra-arterial, Stroke

Received: September 26, 2019, Revised: October 7, 2019, Accepted: October 8, 2019, Published online: December 31, 2019

Correspondence to Haeyoung Suh-Kim

Department of Anatomy, Ajou University School of Medicine, 164 Worldcup-ro, Yeongtong-gu, Suwon 16499, Korea

Tel: +82-31-219-5036, Fax: +82-31-219-5039, E-mail: hysuh@ajou.ac.kr

Co-Correspondence to Sung-Soo Kim

Department of Anatomy, Ajou University School of Medicine, 164 Worldcup-ro, Yeongtong-gu, Suwon 16499, Korea

Tel: +82-31-219-5036, Fax: +82-31-219-5034, E-mail: kimdmg@ajou.ac.kr

${ }^{*}$ These authors contributed equally to this work.

(a) This is an open-access article distributed under the terms of the Creative Commons Attribution Non-Commercial License (http://creativecommons.org/licenses/by-nc/4.0/), which permits unrestricted non-commercial use, distribution, and reproduction in any medium, provided the original work is properly cited.

Copyright (c) 2020 by the Korean Society for Stem Cell Research 


\section{Introduction}

Stroke, which is caused by a reduction or blockage in the blood supply to the brain, is one of the leading causes of death worldwide (1). The timely restoration of cerebral blood flow using recanalization techniques is the most effective strategy for salvaging the ischemic penumbra that is not infarcted but remains highly vulnerable to secondary waves of inflammation (2-4). However, this reperfusion therapy has a short therapeutic time window, thus stroke remains a leading cause of long-term disability worldwide (5). Therefore, the continued development of new treatments for stroke remains imperative.

Stem cell-based therapy has emerged as a promising candidate to alleviate neurological deficits in stroke patients. Mesenchymal stem cells (MSCs) have been identified firstly from the bone marrow as non-hematopoietic stem cells (6) and now can be isolated from adipose tissue, umbilical cord blood, and Wharton's jelly of umbilical cord. MSCs are easily scalable in vitro and their therapeutic effects are mostly ascribed to the paracrine functions by suppressing inflammatory response and providing trophic support. MSCs are thought to be relatively safe due to their low tumorigenic and immunogenic properties compared to other types of stem cells (7-9). For these reasons, MSCs are the first stem cells to have been tested in clinical studies for the treatment of stroke. Preclinical studies demonstrated that administration of MSCs via intracerebral $(10,11)$, intravenous (12-14), intra-arterial (15, 16), and intraventricular/intrathecal routes (17) showed therapeutic benefits of MSCs in animal models of acute stroke (18). Although intravenous administration of autologous MSCs from bone marrow was found to be safe and well tolerated in ischemic stroke patients (19-22), no significant improvement was observed in neurological outcomes following intravenous administration of allogeneic MSCs (23). This lack of improvement may be partly ascribed to the entrapment of the cells in the liver and lungs, lowering the stem cell dose in the ischemic brain $(24,25)$.

Compared to intravenous or intra-cisternal administration, direct (intracerebral) administration proximal to the ischemic area may be advantageous to achieve the maximum dose without transplanted cell loss. In such case, Neurally induced MSCs expressing the neurogenic transcription factor neurogenin 1 (Ngnl) were more effective at alleviating neurological deficits in an animal model of acute stroke than parental MSCs when intracerebrally injected into the ischemic area (11). This increased effectiveness was partly ascribed to the neuronal differentiation of Ngn1-expressing MSCs (MSCs/Ngn1) - these cells survive longer and integrate into host neural circuits in the ischemic stroke model. In contrast, parental MSCs give rise to glial cells only (11). Interestingly, MSCs/Ngnl are also effective when delivered intra-arterially via the carotid artery (26). However, it is not yet clear how neural induction is advantageous for intra-arterial administration, since the cells inside the vascular lumen need to undergo trans-endothelial migration to exert therapeutic effects. More specifically, it is not known whether neural induction enhances cell recruitment to the infarcted area of the brain. If this is the case, the mechanism by which neural induction increases the trans-endothelial migration of endovascular stem cells to injured sites also remains unknown.

In this study, we investigated the effect of neural induction on the intra-arterial delivery of MSCs for the treatment of stroke. By longitudinal analysis using magnetic resonance imaging (MRI), we showed that MSCs/ Ngn1 exhibit increased recruitment to the ischemic brain and populate this area for a longer period of time compared to parental MSCs. We also showed that compared to parental MSCs, MSCs/Ngn1 exhibit increased adherence to brain endothelial cells and increased migration towards the ischemic site. These findings are well correlated to the higher expression of chemotactic cytokine receptors in MSCs/Ngn1. We propose that neurally induced stem cells delivered intra-arterially exhibit enhanced recruitment to the endangered brain area and, once grafted in the brain, survive longer by partly transdifferentiating to neuronal cells.

\section{Materials and Methods}

\section{Study approval}

All experimental protocols using MSCs were approved by the Institutional Review Board of the Ajou University Hospital (AJIRB-GEN-SMP-11-187) and all animal protocols were approved by the Institutional Animal Care and Use Committee of the Ajou University School of Medicine (2015-0012).

\section{Cell culture and genetic modification}

Human MSCs were isolated from bone marrow aspirates and cultured in vitro, as previously described (27). Briefly, mono-nucleated adherent cells were collected and maintained in Dulbecco's modified Eagle's medium (Welgene, Gyeongsan, South Korea) supplemented with $10 \%$ fetal bovine serum (GE Healthcare Life Sciences, Queensland, Australia) $100 \mathrm{U} / \mathrm{ml}$ penicillin, $100 \mathrm{mg} / \mathrm{ml}$ strepto- 
mycin (Invitrogen, Carlsbad, CA, USA) and $10 \mathrm{ng} / \mathrm{ml}$ basic fibroblast growth factor (PeproTech, Rocky Hill, NJ, USA). MSCs/Ngn1 were prepared using a retroviral vector encoding Ngn1 as previously described (11). MSCs/LacZ were prepared using the same retroviral vector encoding bacterial LacZ instead of $\mathrm{Ngn} 1$ and used as a negative control. The cells were used $3 \sim 6$ passages after transduction during the exponential growth phase. To distinguish them from bEnd.3 cells (CRL-2299, ATCC, Manassas VA, USA) in the attachment test, MSCs/LacZ or MSCs/Ngn1 were additionally transduced with pLL3.7, a lentiviral vector expressing green fluorescent protein (GFP) (Addgene, Watertown, MA, USA).

\section{Surface antigen analysis}

MSCs/LacZ and MSCs/Ngn1 were harvested with $0.25 \%$ Trypsin-EDTA (Invitrogen, Carlsbad, CA, USA) and were resuspended in PBS containing 1\% bovine serum albumin (Sigma-Aldrich, St. Louis, MO, USA). The cells were stained with fluorochrome-conjugated antibodies against CD90, HLA-ABC, CD45, CD29, CD73, HLA-DR, CD34, STRO-1, CD105, CD-11b, CD49a, CD117, and CD140b or isotype controls (Biolegend, San Diego, CA, USA) for $15 \mathrm{~min}$ at $22^{\circ} \mathrm{C}$. After washing with PBS containing 1\% BSA, the cells were analyzed with a BD FACSVantage (BD Bioscience, San Jose, CA, USA). All assays included unstained and isotype controls.

\section{Microarray analysis}

The mRNA profiling experiments and analyses using microarray were performed by Macrogen (Seoul, Korea; http://www.macrogen.co.kr). Briefly, the quantity and purity of total RNA were first validated using a NanoDrop spectrophotomer (NanoDrop Technologies, Wilmington, DE, USA) and the RNA integrity was assessed with a Bioanalyzer (Agilent Technologies, Santa Clara, CA, USA). For each technical replicate, 100 ng of total RNA were amplified and labeled using the GeneChip WT (Whole Transcript) Amplification kit as described by the manufacturer (Affymetrix, Santa Clara, CA, USA). Affymetrix GeneChip Human Gene 2.0 ST arrays were hybridized with $5.5 \mu \mathrm{g}$ of labeled sense DNA, washed, stained, and scanned. Affymetrix data were extracted, normalized, and summarized with the robust multi-average method implemented in the Affymetrix Expression Console software. The up-regulated and down-regulated genes were identified based on fold change values and statistical test $\mathrm{p}$ values, and enrichment analysis using the Gene Ontology (GO, http://geneontology.org/) database was performed for these differentially expressed genes.

\section{Transient middle cerebral artery occlusion model and cell transplantation}

Transient focal ischemia was induced by intraluminal filament occlusion of the middle cerebral artery (MCAo) according to a modified procedure originally described by Longa et al. (28). Briefly, male Sprague Dawley rats weighing 250 270 g (Koatech, Pyeongtaek, Korea) were anesthetized with $5 \%$ isoflurane in $70 \% \mathrm{~N}_{2} \mathrm{O}$ and $30 \% \mathrm{O}_{2}$ in an induction chamber and maintained at 3\% isoflurane with a nose cone. The right common carotid artery (CCA), external carotid artery (ECA), and internal carotid artery (ICA) were exposed. A 4-0 monofilament nylon suture with a silicon-coated tip (Doccol Co., Sharon, MA, USA) was advanced from the ECA lumen into the ICA until it blocked the bifurcating origin of the MCA. Two hours after MCAo, animals were re-anesthetized and reperfusion was performed by withdrawing the suture until the tip cleared the lumen of the ECA. Three days after MCAo, the animals were anesthetized as mentioned previously. After the CCA was ligated, a 28-gauge catheter (Vygon GmbH \& Co. KG, Prager Ring 100, Aachen, Germany) as inserted into the ICA bifurcation point through the ECA stump. After the blood flow from the CCA to the ICA was recovered by the release of the CCA occlusion, $1 \times 10^{6}$ cells in $1.2 \mathrm{ml}$ saline were injected via the catheter over the course of $5 \mathrm{~min}$. During the infusion, the pterygopalatine artery was ligated temporarily and was then released after cell transplantation. Blood flow in the ICA was maintained during the administration. An equal volume of saline was used as a control, and the ECA was then permanently ligated.

\section{Assessment of neurological deficits}

All animals were trained for one week before surgery. Rotarod and adhesive-removal tests were conducted to assess the sensory motor function of the rats 1, 7, 14, 21, and 28 days after the MCAo procedure, as previously described $(11,29)$. Briefly, a rotarod cylinder (Ugobasile, Comerio, Italy) was accelerated from 4 to $40 \mathrm{rpm}$ within 5 min, and the length of time that each animal remained on the rotarod cylinder was measured with a cut-off time of $300 \mathrm{sec}$. Data are presented as the mean latency to fall calculated from three trials. For the adhesive removal test, two square dots of adhesive-patch $\left(100 \mathrm{~mm}^{2}\right)$ were used as bilateral tactile stimuli occupying the distal-radial region on the wrist of each forelimb. The time taken for each animal to remove the adhesive dot was recorded with a cut-off time of $300 \mathrm{sec}$. Data are presented as the mean time to remove the dots calculated from three trials. 


\section{Measurement of infarct volume}

MRI scanning was performed at Ajou University Hospital (Suwon, Korea) using a 3.0 Tesla whole-body MRI scanner (Achieva 3.0T X-Series Qasar Dual, Philips Healthcare, Amsterdam, Netherlands) equipped with a gradient system capable of 35 milliteslas/m. A fast-spin echo imaging sequence was used to acquire $\mathrm{T} 2$-weighted anatomical images of the rat brain in vivo using the following parameters: repetition time, 3,000 milliseconds (msec); effective echo time, $120 \mathrm{msec}$; field of view, $55 \times 55 \mathrm{~mm}^{2}$; image matrix, $256 \times 256$; slice thickness, $1.5 \mathrm{~mm}$; flip angle, $90^{\circ}$; pixel size, $0.21 \times 0.21 \mathrm{~mm}^{2}$. A $300-\mathrm{mm}$ diameter quadrature 16-ring birdcage coil arrangement was used for radio frequency excitation, and a 40-mm diameter saddle coil was used for signal detection A total of 15 slices were scanned to cover the whole rat brain. For each slice, the ischemic area from each T2-weighted image was marked manually and calculated using Osiris software (University of Geneva, Geneva, Switzerland). Relative infarct volume (RIV) was normalized as described by Kim et al. (11) and Neumann-Haefelin et al. (30) using the equation RIV= $(\mathrm{LT}-(\mathrm{RT}-\mathrm{RI})) \times \mathrm{d}$, where $\mathrm{LT}$ and $\mathrm{RT}$ represented the areas of the left and right hemispheres in $\mathrm{mm}^{2}$, respectively, RI was the infarcted area in $\mathrm{mm}^{2}$, and $\mathrm{d}$ was the slice thickness $(1.5 \mathrm{~mm})$. RIV was expressed as a percentage of the right hemispheric volume.

\section{In vivo tracking of superparamagnetic iron oxide-labeled cells}

MSCs/LacZ and MSCs/Ngnl were labeled using Feridex (Feridex IV, TaeJoon Pharmaceuticals, Yongsan, Seoul, Korea) and protamine sulfate (Sigma-Aldrich, St. Louis, MO, USA) according to the procedure described by Arbab et al. (31, 32). Feridex incorporation was verified by Prussian blue staining (26). The superparamagnetic iron oxide (SPIO)-labeled cells were injected as described above and their distribution was monitored 30 min, 1 day, and 25 days after injection with MRI analysis. MRI was performed using a 4.7-T animal MRI scanner (Biospec 47/40; Bruker, Karlsruhe, Germany) located in the Korea Basic Science Institute (Ochang, Korea). The animal was placed on a non-magnetic holder equipped with a nose cone for administration of anesthetic gas containing 2\% isoflurane in $70 \% \mathrm{~N}_{2} \mathrm{O}$ and $30 \% \mathrm{O}_{2}$. T2-weighted images were obtained using the following parameters: repetition time (TR), 5,000 msec; echo time (TE), $90 \mathrm{msec}$; average, 4; acquisition matrix, $256 \times 256$; 15 slices with 1-mm thickness; flip angle, $180^{\circ}$. T2*-weighted multi-slice images were acquired using the following parameters: TR, 561 msec; TE, 20 msec; average, 4; acquisition matrix,
256 $\times 256$; 15 slices with 1-mm thickness; flip angle, $30^{\circ}$. The images were analyzed with Para-Vision Acquisition 5.1 (National Instruments, Austin, TX, USA).

\section{Assessment of in vivo distribution of transplanted cells by quantitative PCR}

Quantification of engrafted cells was conducted by human Alu-based real-time PCR at 1 day after the transplantation of MSCs/LacZ and MSCs/Ngn1. Genomic DNA was prepared from the right and left brain hemispheres of the animals using the DNeasy Blood \& Tissue Kit (QIAGEN, Hilden, Germany). The human Alu-specific primers utilized were 5'-CACCTGTAATCCCAGCACTTT-3' (forward) and 5'-CCCAGGCTGGAGTGCAGT-3' (reverse). Real-time PCR was performed in quadruples in $20 \mu 1$ volume containing $10 \mu 1$ Power SYBR Green PCR Master Mix (Applied Biosystems, Foster City, CA, USA), $8 \mu 1$ genomic DNA and $1 \mu 1$ (5 pmol) each primer using StepOnePlus (Applied Biosystems). The PCR protocol consisted of $2 \mathrm{~min}$ of denaturation at $95^{\circ} \mathrm{C}$ followed by 40 cycles of $95^{\circ} \mathrm{C}$ for $15 \mathrm{sec}, 65^{\circ} \mathrm{C}$ for $30 \mathrm{sec}$, and $72^{\circ} \mathrm{C}$ for $30 \mathrm{sec}$. A standard curve was created using a serial dilution of human genomic DNA (0.001 ng $100 \mathrm{ng}$ ) and this was used to extrapolate the amount of human genomic DNA from the engrafted cells in the rat brain. This experiment was conducted in three animals per group and the data are presented as mean \pm standard error of the mean (S.E.).

\section{In vitro migration and adhesion assays}

Migration assays were performed in a in a 6-well Transwell cell culture chamber with $8-\mu \mathrm{m}$ pore polycarbonate membrane insert (Corning Costar, Cambridge, MA, USA). Cells were placed in the upper compartment of the chamber at a density of $1 \times 10^{4}$ cells in $500 \mu 1$ of assay media (DMEM with $2 \%$ fetal bovine serum (FBS)). The lower compartment was loaded with $500 \mu 1$ DMEM and 100 $\mu \mathrm{g} / \mathrm{ml}$ brain ischemic extract (IE). To prepare this IE, 3 days after MCAo, the ipsilateral hemisphere was homogenized in PBS (150 mg tissue/ml) and centrifuged at $12,000 \times \mathrm{g}$ at $4^{\circ} \mathrm{C}$, and the supernatant was then harvested. After the transwell apparatus was incubated for $4 \mathrm{~h}$ at $37^{\circ} \mathrm{C}$ in $5 \% \mathrm{CO}_{2}$, the cells adhering to the upper side of the membrane were removed with a cotton swab, and transmigrated cells at the bottom side of the membrane were visualized with Hoechst 33258 dye (Invitrogen, Carlsbad, CA, USA) using an Olympus IX71 microscope (Olympus Optical Co. Ltd., Shinjuku, Tokyo, Japan). The average number of cells from four random fields of view $(100 \times)$ was calculated for each well. The results from 
3three independent experiments are presented as mean \pm S.E.

To assess the adhesion of MSCs to endothelial cells in vitro, a mouse brain endothelial cell line, bEnd.3 was grown to confluence in growth medium (DMEM with 10\% FBS) in a 6-well plate. To mimic ischemic conditions, bEnd. 3 cells were stimulated with $10 \%$ IE in $1 \mathrm{ml}$ growth medium for 3 h. $2.5 \times 10^{4}$ GFP-labeled $\mathrm{MSCs} / \mathrm{LacZ}$ or MSCs/Ngnl were added to the monolayer cultured bEnd.3 cells and allowed to attach for indicated time up to $4 \mathrm{~h}$. The monolayer culture was washed with PBS twice and fluorescent images of the remaining GFP-labeled cells were acquired with an Olympus IX71 microscope. The average number of GFP-positive cells from four random visual fields $(100 \times)$ was calculated for each well. The results from three independent experiments are presented as mean \pm S.E.

\section{Real-time PCR analysis}

Total RNA was extracted from MSCs/LacZ and MSCs/ Ngn1 using RNAzol B (Tel-Test; Friendswood, TX, USA), and cDNA was synthesized from $1 \mu \mathrm{g}$ total RNA using the First Strand cDNA Synthesis Kit (Invitrogen, Carlsbad, CA, USA), according to the manufacturer's recommendations. Real-time PCR was performed to quantify the expression of chemokine receptors using StepOnePlus Real-Time PCR system (Applied Biosystems). Each $20 \mu 1$ reaction mixture contained 5 pmol of each primer, $10 \mu 1$ Power SYBR Green PCR Master Mix (Applied Biosystems), and $100 \mathrm{ng}$ cDNA. The PCR protocol consisted of 2 min of denaturation at $95^{\circ} \mathrm{C}$ followed by 40 cycles of $95^{\circ} \mathrm{C}$ for $15 \mathrm{sec}, 65^{\circ} \mathrm{C}$ for $30 \mathrm{sec}$, and $72^{\circ} \mathrm{C}$ for $30 \mathrm{sec}$. The primer sequences utilized are summarized in Table 1.

\section{Histological analysis}

For immunohistochemical analysis, animals were anesthetized with ketamine $(100 \mathrm{mg} / \mathrm{kg}) /$ xylazine $(10 \mathrm{mg} / \mathrm{kg})$ (Yuhan Co. Ltd., Seoul, Korea), perfused transcardially with ice-cold saline, and then fixed with $10 \%$ neutral buffered formalin $(\mathrm{NBF})$. The brains were post-fixed in $10 \%$ $\mathrm{NBF}$ and embedded in paraffin. The paraffin blocks were serially sectioned to produce $5-\mu \mathrm{m}$ thick sections, which were then deparaffinized and placed in boiled citrate buffer ( $\mathrm{pH}$ 6.0) for $10 \mathrm{~min}$. After blocking in 10\% normal serum, the sections were incubated with antibodies against neuronal nuclei (NeuN; 1 : 500, Merck Millipore, Burlington, MA, USA), microtubule-associated protein 2 (MAP2; 1 : 500, Sigma-Aldrich, St. Louis, MO, USA), human mitochondrial antigen (1:100, Merck Millipore), GFP (1: 500, Abcam, Cambridge, UK), RECA-1 (1 : 50, Abcam), and ED1 (1 : 200, AbD Serotec, Kidlington, UK) at $4^{\circ} \mathrm{C}$ overnight. Antibody reactions were visualized using an ABC kit (Vector Laboratories, Burlingame, CA, USA) according to the manufacturer's instructions. A Prussian blue staining method (31) was used to identify Feridex incorporation in the MSCs/LacZ and MSCs/Ngn1. Apoptotic cells were analyzed with the In Situ Cell Death Detection Kit (Roche Diagnostics, Mannheim, Germany) according to the manufacturer's instructions. Alternatively, brains were removed after perfusion and cryoprotected in $30 \%$ sucrose in $0.1 \mathrm{M}$ phosphate buffer ( $\mathrm{pH} 7.4$ ) overnight. The cryopreserved brains were sectioned to produce 30 $\mu \mathrm{m}$-thick sections which were then incubated with Alexa Fluor 488- or 568-conjugated anti-IgG secondary antibodies (Life Technologies, Carlsbad, CA, USA).

For quantification of terminal deoxynucleotidyl transferase dUTP nick end labeling- (TUNEL-), ED1-, and NeuN-positive cells in the ischemic penumbra, $5 \mu \mathrm{m}$ coronal sections from the ischemic core (Antero-Posterior, $+1.2 \mathrm{~mm}$ to $-0.8 \mathrm{~mm}$ from the bregma) were prepared from three animals. Light microscopic images were acquired using an AxioScan.Z1 slide scanner (Zeiss, Jena, Germany), and the total number of immuno-reactive cells in $1 \mathrm{~mm}^{2}$ regions of interest in the peri-infarct area of the cortex and striatum were counted using ZEN software (Blue Edition, Zeiss). To trace GFP-positive cells, $30 \mu \mathrm{m}$ coronal sections from the ischemic central region were scanned with an AxioScan.Z1 equipped with an $\mathrm{HBO}$ lamp (HXP 120V, LEJ, Jena, Germany). The total number

Table 1. Primers for quantitative real-time PCR

\begin{tabular}{cl}
\hline Gene & \multicolumn{1}{c}{ Primer sequence } \\
\hline CCR1 & $\mathrm{F}:$ GACTATGACACGACCACAGAGT \\
& $\mathrm{R}:$ CCAACCAGGCCAATGACAAATA \\
CCR2 & $\mathrm{F}:$ CCACATCTCGTTCTCGGTTTATC \\
& $\mathrm{R}:$ CAGGGAGCACCGTAATCATAATC \\
CXCR4 & $\mathrm{F}:$ ACTACACCGAGGAAATGGGCT \\
& $\mathrm{R}:$ CCCACAATGCCAGTTAAGAAGA \\
VLA-4 & $\mathrm{F}:$ TACAGATGCAGGATCGGAAAGA \\
& $\mathrm{R}:$ AGGTTCTCCATTAGGGCTACC \\
CD44 & $\mathrm{F}:$ CTGCCGCTTTCAGGTGTA \\
& $\mathrm{R}:$ CATTGTGGGCAAGGTGCTATT \\
TGF- $\beta$ & $\mathrm{F}:$ GGCCAGATCCTGTCCAAGC \\
& $\mathrm{R}:$ GTGGGTTCCACCATTAGCAC \\
GAPDH & $\mathrm{F}:$ GTCTCCTCTGACTTCAACAGCG \\
& $\mathrm{R}:$ ACCACCCTGTTGCTGTAGCCAA
\end{tabular}

CCR1: C-C chemokine receptor type 1, CCR2: C-C motif chemokine receptor 2, CXCR4: C-X-C motif chemokine receptor 4, VLA-4: very late antigen-4 (integrin alpha4betal), TGF- $\beta$ : transforming growth factor- $\beta$. 
of GFP-positive cells in the ischemic hemisphere was counted in 10 serial sections per animal. The results from three animals are presented as mean \pm S.E.

\section{Statistical analysis}

Statistical analyses were carried out using Sigmaplot (Systat Software Inc, San Jose, CA, USA). Data were analyzed by Student's $t$-test or one-way analysis of variance (ANOVA). Significant differences were further evaluated using Tukey's honest significant difference post-hoc test. A p value $<0.05$ was considered statistically significant. All data are expressed as mean \pm S.E.

\section{Results}

\section{Differentially expressed genes between MSCs/LacZ and MSCs/Ngnl}

Following the transduction of MSCs with a retroviral vector encoding Ngn1, the expression of Ngn1 was examined at the mRNA level. MSCs expressing $\beta$-galactosidase (LacZ) were used as controls (Fig. 1A). The cell surface characteristics of MSCs/LacZ and MSCs/Ngnl were analyzed by flow cytometry analysis. MSCs/LacZ and MSCs/ Ngn1 were positive for CD90, HLA-ABC, CD29, CD49a, CD73, and CD105, but negative for STRO-1, CD34, HLA-DR, CD11b, CD117, and CD140b (Supplementary Table S1). This similarity indicates that Ngn1 does not alter the general surface antigenicity of MSCs.

To compare the overall gene expression profiles of MSCs/Ngnl and MSCs/LacZ, microarray analyses were performed. This comparison revealed significant changes in a total of 292 genes between MSCs/Ngn1 and MSCs/ LacZ (140 up-regulated and 152 down-regulated) with a fold change $>1.5$ (Fig. 1D). To identify the key biological processes associated with these differentially expressed genes, GO enrichment analysis was conducted. The key GO terms significantly enriched were cell motility (GO: 0048870) and locomotion (GO:0040011). The commonly up- or down-regulated genes were significantly associated with the following GO terms: movement of cell or subcellular component, localization of cell, extracellular structure organization, extracellular matrix organization, cell adhesion, biological adhesion, response to virus, response to type I interferon, interferon-gamma-mediated signaling pathway, response stimulus, and immune system process (Fig. 1E). Although some of these might be ascribed to retroviral transduction, the GO enrichment analysis ultimately indicated that the predominant effects of MSCs/ Ngn1 were on cell migration and extracellular matrix organization. RT-PCR analysis indicated that MSCs/Ngn1 expressed higher levels of CCR1, CCR2, CXCR4, VLA-4, and CD44 than MSCs/LacZ. The mRNA level of transforming growth factor beta (TGF- $\beta$ ) was comparable between MSCs/LacZ and MSCs/Ngn1 (Fig. 1C), suggesting that MSCs acquire molecular tools for increased migration following Ngn1 transduction.

\section{Enhanced adhesion and migration activity of MSCs/Ngnl}

To determine whether the increased expression of chemokine receptors in MSCs/ $\mathrm{Ngn} 1$ correlated with enhanced migratory and endothelial cell adhesion ability, transwell migration and endothelial cell adhesion assays were conducted. To mimic ischemic conditions, brain IE was added to the assay (Fig. 2A). In the transwell migration assay, MSCs/Ngn1 migrated towards the IE placed in the lower chamber at a faster rate than MSCs/LacZ (Fig. 2B, 2C). A monolayer culture of bEnd.3 endothelial cells was primed with IE and GFP-labeled MSCs/LacZ or MSCs/ Ngn1 were added to the culture. A higher number of GFP-labeled MSCs/Ngn1 adhered to the bEND.3 cells than GFP-labeled MSCs/LacZ (Fig. 2D, 2E). These results suggest that the increased expression of chemokine receptors in MSCs/Ngn1 may lead to enhanced migration and endothelial cell adhesion in the presence of brain IE.

\section{Engraftment of MSCs/Ngnl in the acute ischemic brain}

To test whether neural induction with Ngn1 enhanced the homing activity of MSCs in vivo, longitudinal MRI analysis was conducted. To track the transplanted cells, the cells were labeled with SPIO, an MRI dye (Fig. 3A). SPIO-labeled MSCs/LacZ and MSCs/Ngnl were injected into the ischemic brain via the right ICA and the cells were detected as hypointense signals in T2-weighted images (Fig. 3B). Ultimately, $30 \mathrm{~min}$ after intra-arterial injection, a technically earliest time point, similar levels of both cell types were scattered throughout the ipsilateral side of the brain. Hypointense SPIO signals gradually disappeared in both groups, but this reduction occurred at a lower rate in the MSCs/Ngnl group compared to the MSCs/LacZ group. Indeed, 25 days after intra-arterial injection, the signals remained only in the MSCs/Ngnl group. To confirm the increased engraftment of MSCs/ Ngn1, the cells were labeled with GFP and the number of surviving GFP-positive cells in the entire ischemic hemisphere encompassing the striatum was counted. The number of GFP-positive cells was similar between the groups $4 \mathrm{~h}$ after intra-arterial injection. However, 1 day after injection, the number of GFP-positive cells was high- 
A
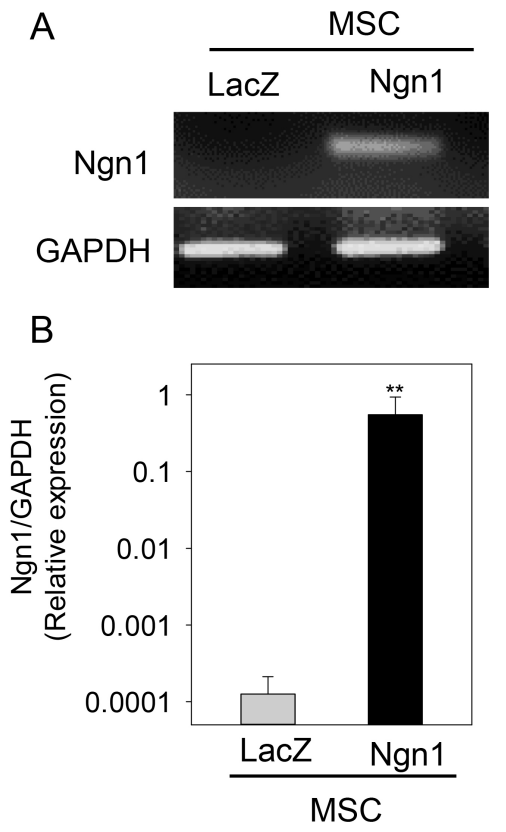

$\mathrm{E}$

Top $10 \mathrm{GO}$ terms of associated biological processes from Fold change $>1.5$
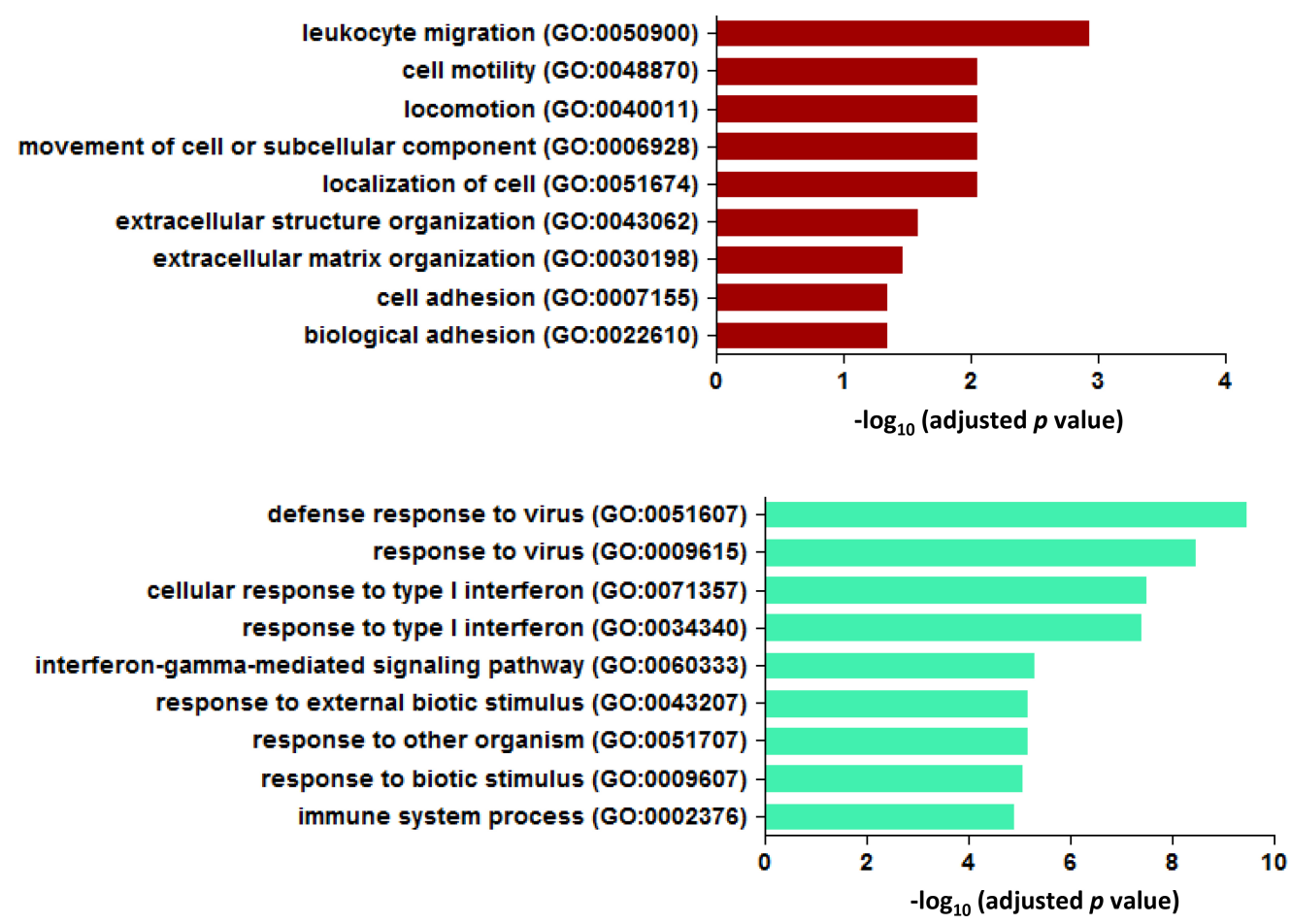

Fig. 1. Comparison of the gene expression profile of mesenchymal stem cells expressing LacZ (MSCs/LacZ) and mesenchymal stem cells expressing neurogenin 1 (MSCs/Ngn1). (A) Expression of neurogenin 1 (Ngn1) in MSCs/Ngn1 was verified by real-time PCR analysis. Glyceraldehyde 3-phosphate dehydrogenase (GAPDH) was used as an internal control. (B) Quantitative assessment of Ngn1 mRNA expression in MSCs/Ngn1. MSCs/LacZ were used as negative controls for transduction. (C) Relative mRNA expression of chemokine receptors and transforming growth factor beta (TGF $\beta$ ) in MSCs/LacZ and MSCs/Ngn1. (D) Microarray analysis showing differentially expressed genes with a fold change $>1.5$ in MSCs/Ngn1 compared to MSCs/LacZ. (E) Gene Ontology (GO) enrichment analysis revealed that the key $\mathrm{GO}$ terms were leukocyte migration, cell motility, and locomotion. Data are presented as mean \pm S.E. Statistically significant differences between MSCs/Ngn1 and MSCs/LacZ are indicated $\left({ }^{* *} \mathrm{p}<0.01,{ }^{* * *} \mathrm{p}<0.001\right.$; Student's $t$-test). 

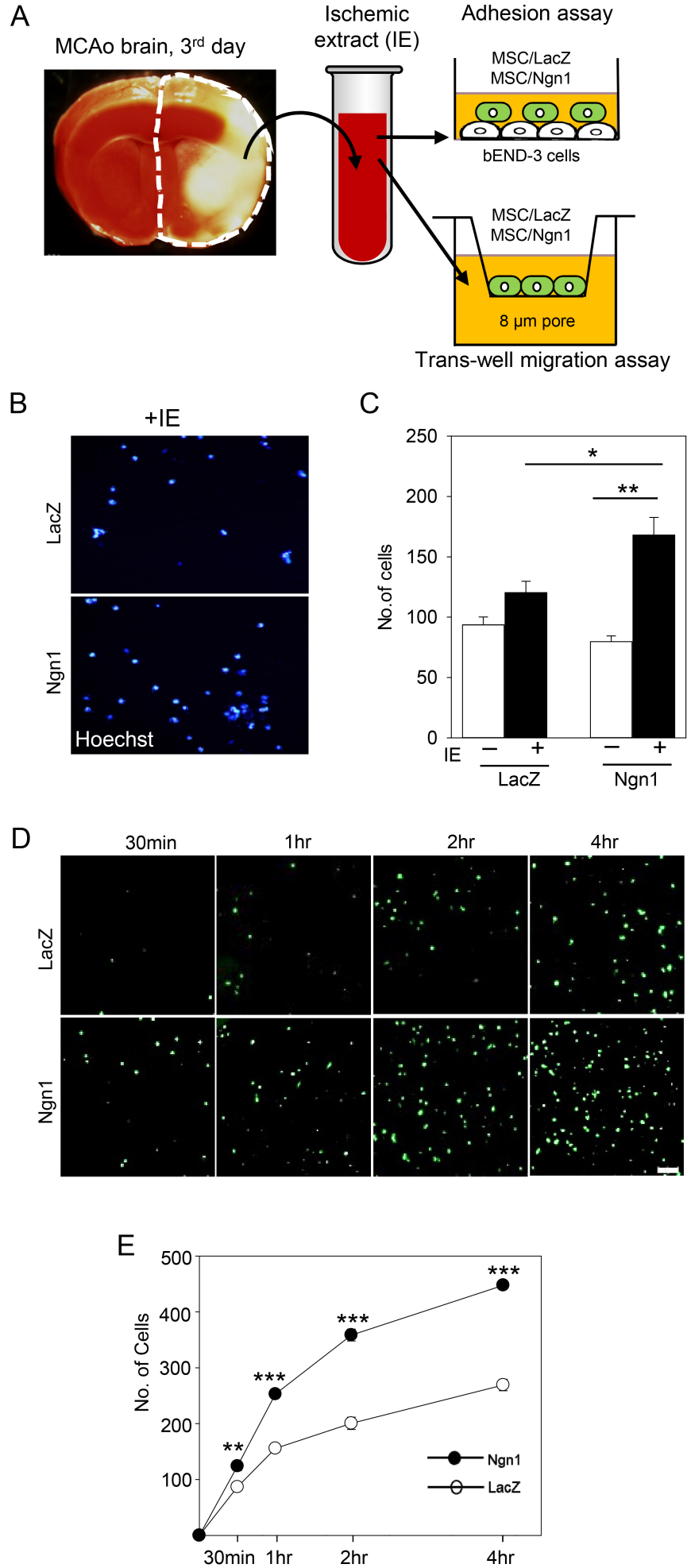

Fig. 2. Enhanced adhesion and migration activity of mesenchymal stem cells expressing neurogenin 1 (MSCs/ Ngn1). (A) Schematic diagram showing the experimental procedures of the adhesion and transwell migration assays. (B) Transwell migration assay showing Hoechst-stained mesenchymal stem cells expressing LacZ (MSCs/LacZ) and MSCs/Ngn1 in the bottom layer. (C) Quantification of Hoechst-stained cells that migrated to the bottom compartment containing the brain ischemic extract (IE) over a $4 \mathrm{~h}$ period. (D) Florescence image showing green fluorescent protein- (GFP-) positive MSCs/LacZ and MSCs/Ngn1 adhering to IE-stimulated bEnd.3 cells. (E) Quantification of GFP-positive cells following a $4 \mathrm{~h}$ adhesion assay. At least four random fields were used to obtain the number of adherent cells. Data are presented as mean \pm S.E. from three independent experiments. Statistically significant differences between MSCS/ Ngn1 and MSCs/LacZ are indicated $\left({ }^{*} \mathrm{p}<0.05,{ }^{* *} \mathrm{p}<0.01,{ }^{* * *} \mathrm{p}<0.001\right.$; Student's $t$-test). er in the MSCs/Ngn1 group (Fig. 3C, 3D). GFP-positive cells were mostly detected in the vascular lumen at $4 \mathrm{~h}$ but extravasated into the brain parenchyma 1 day after transplantation (Supplementary Fig. S1).
To further verify the tissue distribution of transplanted cells, real-time PCR analyses were conducted using human Alu-specific primers (Fig. 3E, 3F). To extrapolate the genomic DNA derived from human MSCs, a standard 

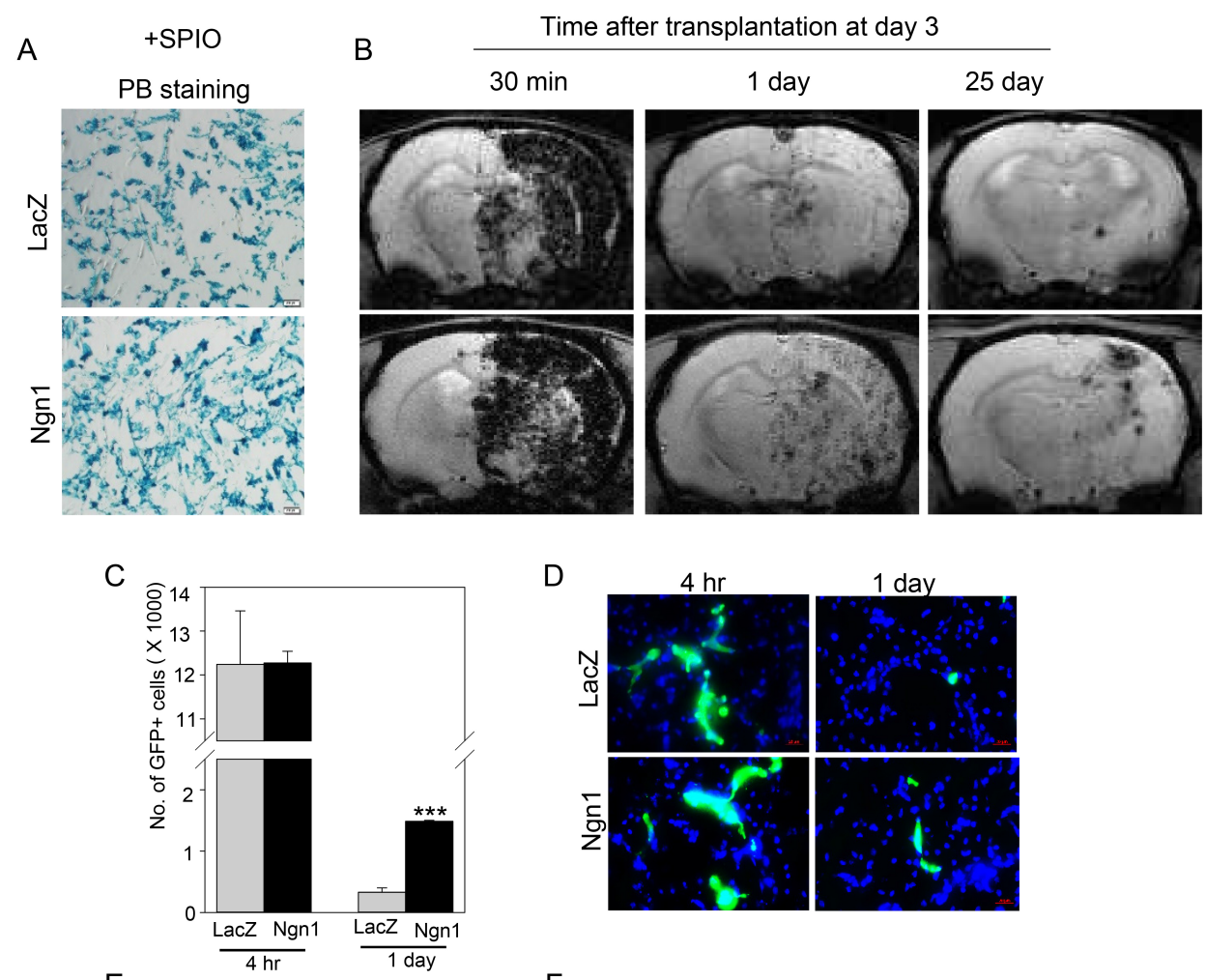

$\mathrm{D}$

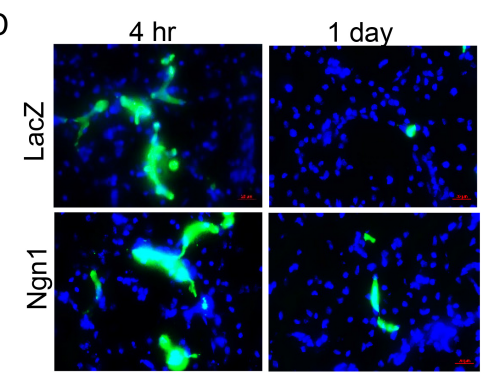

E

$\mathrm{F}$
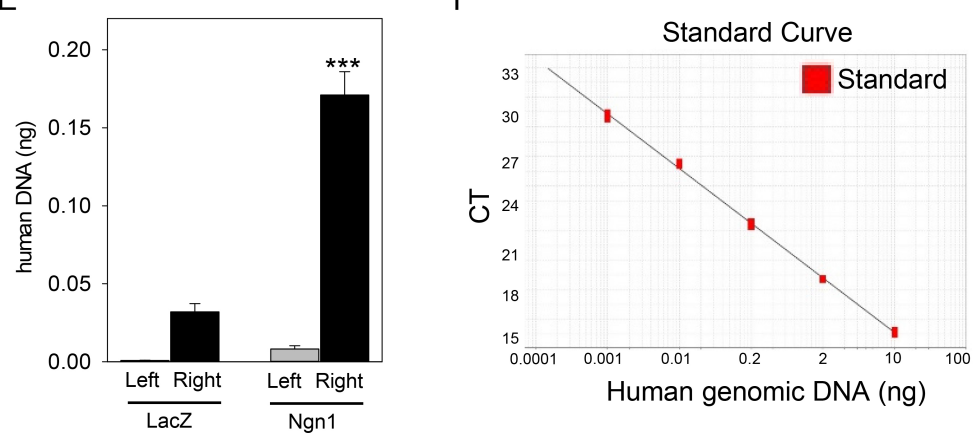

G
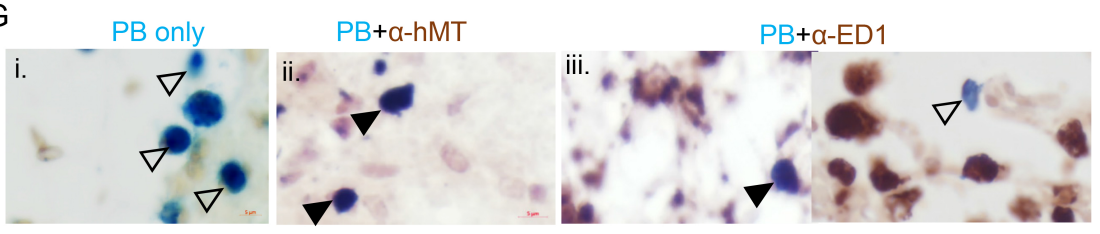

Fig. 3. Enhanced engraftment of mesenchymal stem cells expressing neurogenin 1 (MSCs/Ngn1) in the acute ischemic brain. (A) Prussian blue (PB) staining of superparamagnetic iron oxide (SPIO)-labeled mesenchymal stem cells expressing LacZ (MSCs/LacZ) and MSCs/Ngn1 in vitro. (B) T2* magnetic resonance imaging was used to assess the distribution and engraftment of intra-arterially injected MSCs/LacZ in the ischemic brain over a period of 25 days after transplantation. (C) Quantification of engrafted MSCs/LacZ and MSCs/Ngn1 in the ischemic hemisphere by green fluorescent protein (GFP) fluorescence $4 \mathrm{~h}$ and 1 day after injection. The data were obtained from 10 serial sections of 3 independent animals and are presented as mean per section \pm S.E. ( ${ }^{* *}$ p $<0.001$ compared to MSCs/LacZ group; Student's t-test). (D) GFP-positive cells were prominent in the vascular lumen $4 \mathrm{~h}$ after transplantation, and were found in the perivascular area of the brain parenchyma in the MSCs/Ngn1 group. (E) Human Alu-specific PCR analysis revealed enhanced engraftment of MSC/Ngn1 compared to MSCs/LacZ 1 day after transplantation. Experiment was conducted in three animals per group and the data are presented as mean \pm standard error of the mean (S.E.). ( ${ }^{* *} p<0.001$ compared to right hemisphere of MSCs/LacZ group; Student's $t$-test). (F) A standard curve with human Alu-specific PCR was used to extrapolate the amount of human DNA in the rat brain. (G) Prussian blue staining revealed SPIO-labeled MSCs/Ngn1 25 days after injection (blank arrowheads). Immunostaining for human mitochondria antigen (hMT) or ED1 along with Prussian blue staining revealed MSCs/Ngn1 or cells engulfed by phagocytic cells in the penumbra 25 days after injection, respectively (filled arrowheads). 
curve was created using a serial dilution of human genomic DNA from MSCs with a limit of detection of $1 \mathrm{pg}$ human DNA in $100 \mathrm{ng}$ rat DNA (Fig. 3F). One day after injection, human genomic DNA was detected higher by 5.3-fold in the ischemic right hemisphere of the MSCs/ Ngn1 group than the MSCs/LacZ group (Fig. 3E). The

A

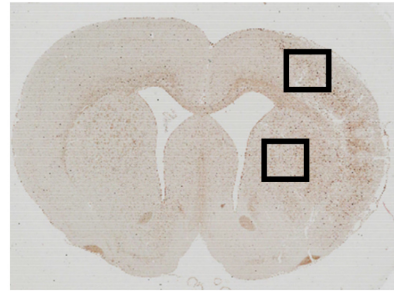

B

TUNEL

ED1

NeuN
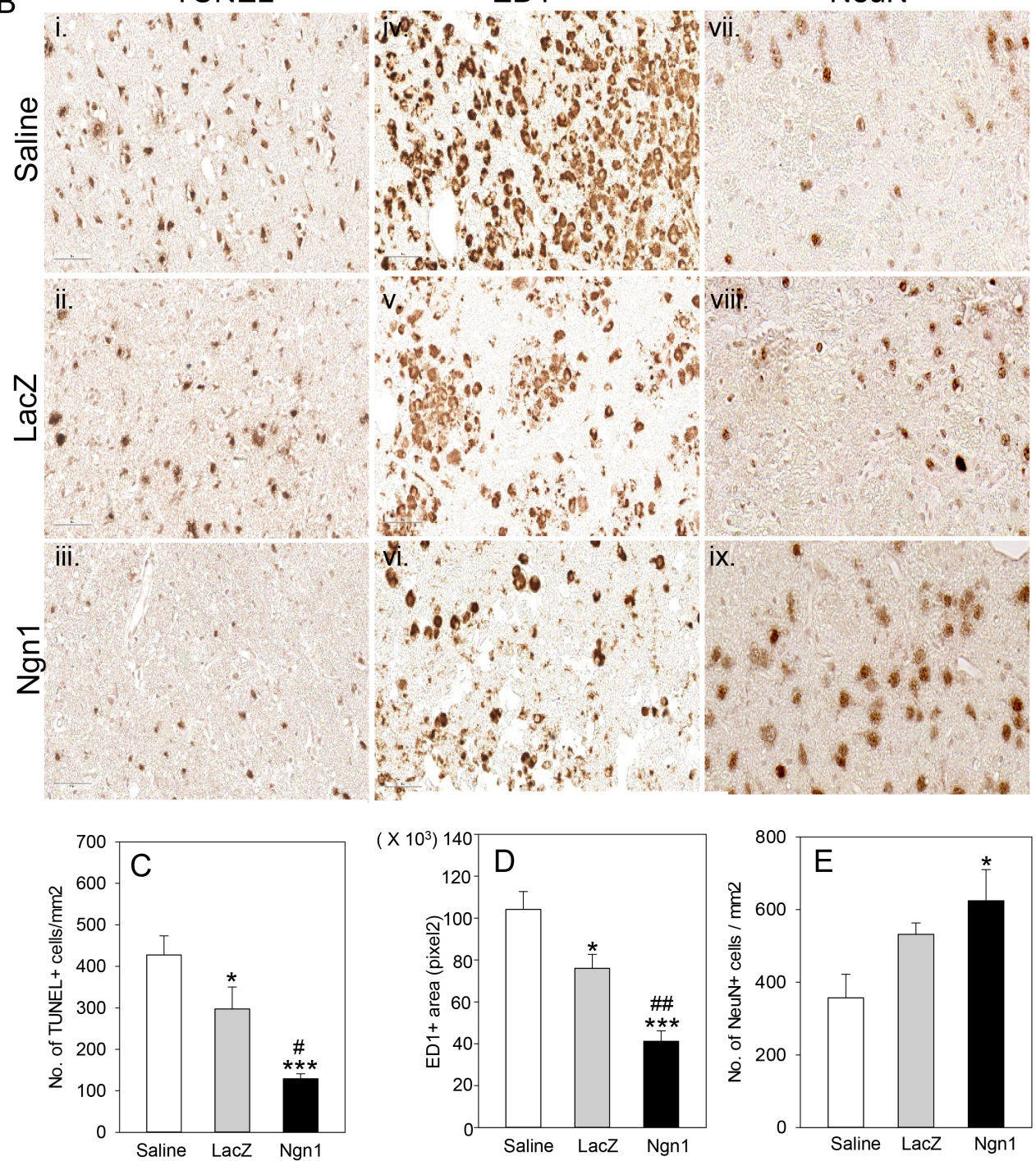

Fig. 4. Neuroprotective effects of mesenchymal stem cells expressing neurogenin 1 (MSCs/Ngn1 cells). (A) Low magnification light microscopy showing cortical and striatal ischemic penumbra region used for quantification of terminal deoxynucleotidyl transferase dUTP nick end labeling- (TUNEL-), ED1- and neuronal nuclei- (NeuN-) positive cells. (B) Representative photographs of TUNEL staining and ED1 immunostaining 4 days after cell transplantation and NeuN immunostaining 25 days after cell transplantation. Quantification of TUNEL-, ED1, and NeuN- positive cells are illustrated in $(C \sim E)$, respectively. Results from three animals are presented as mean $\pm S . E$. $\left({ }^{*} p<0.05, * * * p\right.$ $<0.001$ compared to saline group and ${ }^{\#} \mathrm{p}<0.05,{ }^{\#} \mathrm{p}<0.01$ compared to MSCs/LacZ group; One-way Anova). 
level of genomic DNA of MSCs were minimal in the contralateral hemisphere, indicating the specificity of our PCR assay. Furthermore, 25 days after cell injection, the MSCs/Ngn1 were detected as Prussian blue-positive cells (Fig. 3G) which were co-localized with a human-specific mitochondrial antigen. Although few surviving MSCs/ Ngn1 differentiated into NeuN- or MAP2-positive neuronal cells (Supplementary Fig. S2), most Prussian blue-positive cells were co-localized with ED1-positive cells, indicating that transplanted MSCs/Ngnl were mostly engulfed by ED1-positive phagocytic cells. Taken together, these results indicate that compared to $\mathrm{MSCs} / \mathrm{LacZ}$, MSCs/Ngn1 exhibit a higher extravasation rate and remain stable in the ischemic brain while maintaining neuronal differentiation potential for 25 days after transplantation (28 days after MCAo).

\section{Neuroprotective effects of MSCs/Ngnl}

To determine the paracrine effects of $\mathrm{MSCs} / \mathrm{Ngn} 1$ in acute stroke, we assessed apoptotic cell death, inflammation, and neuroprotection with TUNEL-, ED1-, and NeuN-specific staining in the ischemic penumbra, respectively. In the MSCs/Ngnl group, the number of TUNELpositive apoptotic cells was significantly reduced compared to the MSCs/LacZ group (Fig. 4B, 4C) 4 days after intra-arterial injection. Similarly, immunohistochemical staining for ED1, a marker of macrophage infiltration in the ischemic penumbra, revealed significantly reduced infiltration of ED1-positive cells in the ischemic penumbra of the MSCs/Ngn1 group compared to the MSCs/LacZ group (Fig. 4B, 4D). To investigate if this reduction in apoptotic cell death and inflammation in the ischemic penumbra promoted neuronal survival, we stained for $\mathrm{NeuN}$ in the ischemic penumbra 4 weeks after the ischemic injury. We observed that the number of NeuN-positive cells was significantly higher in the ischemic penumbra of MSCs/Ngnl-injected animals compared to MSCs/LacZand saline-injected animals (Fig. 4B, 4E). These results indicated that transplantation of MSCs/Ngn1 exerts greater neuronal protection, which, at least in part, correlates with increased engraftment of the cells in the ischemic brain.

\section{Improved functional recovery with MSCs/Ngnl}

To test whether the increased homing ability of MSCs/ Ngn1 and the enhanced neuroprotection associated with their transplantation correlated with improved behavioral function and brain tissue integrity, rotarod and adhesive removal tests and MRI analysis, respectively, were conducted. In the rotarod and adhesive removal tests, the saline-treated animals showed spontaneous recovery to a limited degree in the 28 days following MCAo (25 days after intra-arterial injection). Compared to saline, transplantation of MSCs/LacZ induced greater functional recovery. Importantly, the greatest functional recovery was observed
A

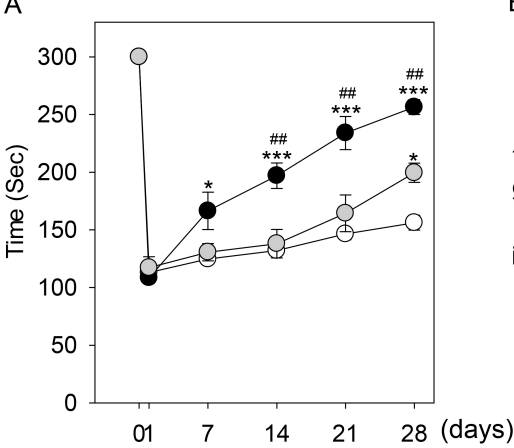

B

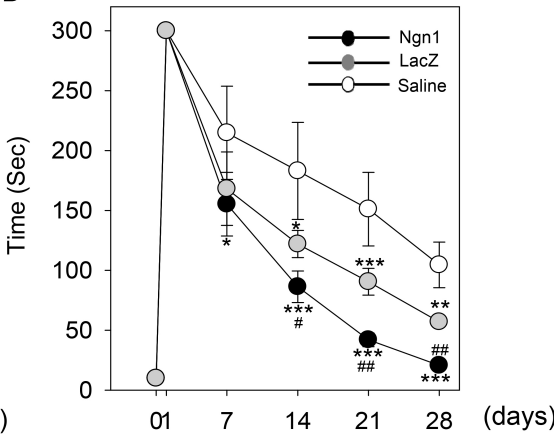

C

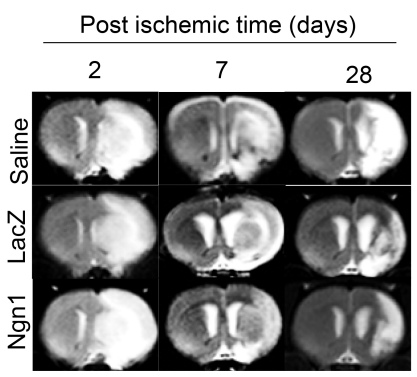

D

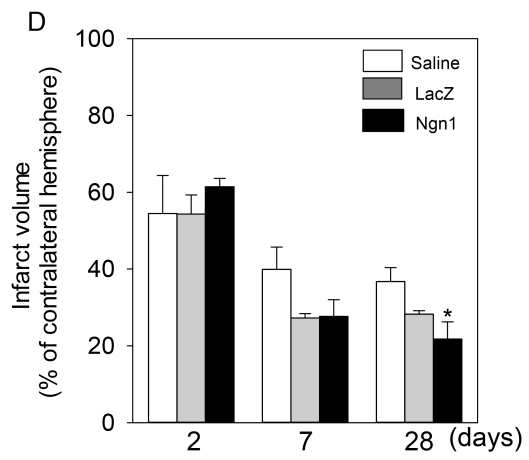

Fig. 5. Improved functional recovery and tissue integrity following mesenchymal stem cells expressing neurogenin 1 (MSCs/Ngn1) transplantation. Behavioral performance in the rotarod (A) and adhesive removal tests (B) up to 28 days after ischemia. Data were collected from at least five animals per group and are presented as mean \pm S.E. (C) Representative magnetic resonance image showing the infarcted area. (D) Quantification of magnetic resonance images from days $2 \sim 28$ reveals the infarct volume as mean \pm S.E. $\left({ }^{*} \mathrm{p}<0.05\right.$, $* * * p<0.001$ compared to saline group and ${ }^{\#} p<0.05,{ }^{\#} p<0.01$ compared to MSCs/LacZ group; One-way Anova). 
following transplantation of MSCs/Ngn1 (Fig. 5A, 5B). We also assessed the structural integrity of the ischemic brain over the same 28-day period using MRI. The hyperintense areas in T2-weighted images over the central eight images (1.5-mm-thick section) were combined to obtain the infarct volume (Fig. 5C, 5D). This analysis showed that 2 days after MCAo, the initial infarct volume was $56.7 \pm 11.8 \%$ of the intact contralateral hemisphere. In the saline-injected group, the infarct volume decreased spontaneously to $39.9 \pm 11.1 \%$ at day 7 and then remained constant up to 28 days $(36.7 \pm 6.3 \%)$. Seven days after MCAo, the infarct volumes of the MSCs/LacZ and MSCs/Ngn1 groups were similar $(27.1 \pm 1.9 \%$ and $27.7 \pm 7.5 \%$, respectively). However, while the infarct volume remained constant $(28.2 \pm 2.0 \%)$ up to 28 days in the MSCs/LacZ group, it continued to decrease to $21.7 \pm 7.7 \%$ in the MSCs/Ngn1 group. These results indicate that intra-arterial transplantation of $\mathrm{MSCs} / \mathrm{Ngn} 1$ in acute stroke (3 days after MCAo) effectively blocks neuronal cell death and brain inflammation, and consequently preserves tissue integrity and enhances behavioral recovery.

\section{Discussion}

Although the therapeutic potential of MSCs is widely accepted, it is challenging to efficiently deliver these cells proximal to injury or disease sites. The most convenient delivery method is systemic administration, which is less invasive than direct administration to the damaged or penumbral parenchyma, and is thus preferred for acute stroke therapy. However, intravenous administration distributes MSCs mostly in the lungs, spleen, and liver (25, 33), which lowers the effective dose in the damaged brain.

In this study, we investigated the effect of neural induction on the efficacy of intra-arterial delivery of MSCs for the treatment of stroke. Microarray analysis of the gene expression profiles of parental MSCs/LacZ and MSCs/Ngn1 yielded 292 differentially expressed genes (140 up-regulated and 152 down-regulated). GO enrichment analysis revealed that these differentially expressed genes were associated with cell motility and migration pathways (Fig. 1E). Quantitative RT-PCR analysis validated that the expression of the chemokine receptors CCR1, CCR2, and CXCR4 was higher in MSCs/Ngn1. Given that the cognate ligands for these receptors, namely macrophage inflammatory protein-1 (34), monocyte chemoattractant protein-1/cytokine (C-C motif) ligand 2 (35), and stromal cell-derived factor-1 (36) are upregulated in the ischemic brain, it is very likely that MSCs/Ngnl have a higher tendency to be recruited to the damaged brain
(Fig. 3). In vitro migration assays revealed that MSCs/ Ngnl exhibited higher tropism from the upper chamber towards the brain IE in the bottom chamber (Fig. 2B, 2C). To exit the vascular lumen and populate the damaged tissue, a series of processes is required including tethering/rolling, adhering, and trans-endothelial migration. MSCs/Ngn1 exhibited increased adherence to IE-primed brain endothelial bEnd.3 cells (Fig. 2D, 2E). These in vitro data correlate well with the increased recruitment of MSCs/Ngn1 to the infarcted area, as shown in Fig. 3.

SPIO-enhanced MRI analysis revealed that the cells injected through the ECA sequentially flowed into the ICA, ACA, and MCA, and were then widely distributed in the ipsilateral hemisphere (Fig. 3). Whether these cells are parental MSCs (MSCs/LacZ) or neurally induced MSCs (MSCs/Ngn1) does not seem to be of importance with respect to destination, since the SPIO-enhanced MR signal intensity $30 \mathrm{~min}$ after injection was similar between the two groups (Fig. 3B). It has previously been shown that injection through the portal vein yields increased MSC engraftment in the liver than injection through the tail vein $(33,37)$. These results together with ours indicate that MSC delivery through the vasculature near the target site is advantageous by preventing the cells from being entrapped in the lung. The SPIO signals are dramatically reduced at 1 day after injection with a lower deceleration rate for MSCs/Ngnl (Fig. 3B). Thus, more of MSCs/Ngnl cells remain compared to $\mathrm{MSCs} / \mathrm{LacZ}$ as tested by histological analysis for GFP-labeled cells in the ischemic brain (Fig. 3C, 3D) and by quantitative PCR analysis conducted with human specific-Alu primers (Fig. 3E, 3F). Eventually, most SPIO signals disappear at 25 days after injection. Immuohistochemical analysis reveals that remnant SPIO signals are due to the ferridex particles taken up by ED1+ phagocytic cells although rare MSCs/Ngnl cells could be found as NeuN+ cells (Supplementary Fig. S2A). Importantly, a slow infusion rate $(0.24 \mathrm{ml} / \mathrm{min})$ and low cell dose $\left(1 \times 10^{6}\right.$ cells) of MSCs used in our study did not aggravate stroke damage which is consistent with the report by Janowski et al. (38). When delivered intra-arterially 3 days after ischemic injury, MSCs/Ngn1 more effectively alleviated neurological dysfunction than MSCs/LacZ (Fig. $5 \mathrm{~A}, 5 \mathrm{~B})$. The enhanced motor function seen after MSCs/ Ngn1 delivery is, at least in part, a result of the greater suppression of neuronal cell death and brain inflammation (Fig. 4). In a prior study, MSCs transplanted directly into the ischemic penumbra 3 days after ischemic injury effectively suppressed the infiltration of ED1-positive inflammatory cells from systemic blood via the secretion of TGF- $\beta 1$, subsequently ameliorating neurological 
dysfunction (39). Since the expression of TGF- $\beta 1$ in MSCs/LacZ and MSCs/Ngnl was similar (Fig. 1C), it is likely that the anti-inflammatory effect is not cell type-specific but rather proportional to the number of repopulating cells in the ischemic brain. After trans-endothelial migration to the ischemic penumbra, MSCs/Ngn1 populate this area and secrete TGF- $\beta 1$ for a longer period of time. However, it remains to be clarified whether MSCs/Ngnl secrete other cytokines or neurotropic factors which exert beneficial effects.

In summary, intravenous injection of naïve MSCs is popular for the treatment of stroke $(23,40)$. The therapeutic effects observed in clinical studies have been primarily attributed to the immunomodulatory functions of MSCs. Less invasive routes such as intravenous transplantation may not be appropriate for the treatment of brain diseases such as stroke. Here, we provide evidence that the systemic delivery of stem cells through the ICA could efficiently deliver cells proximal to the ischemic area and bypass the shortcomings of intravenous delivery. Given that the same route has been utilized to deliver thrombolytic agents such as tissue plasminogen activator in hyper-acute stroke patients, the intra-arterial delivery of stem cells may be practically feasible. In this case, neurally induced MSCs may be more advantageous than naïve MSCs.

\section{Acknowledgments}

This study was supported by a grant from the Korean National Research Foundation (NRF-2010-0023676 to S-S.K. and 2018M3A9G1082594 to H.S-K.); and the INNOPOLIS Foundation Jeonbuk (2019-JB-RD-0048-01101).

\section{Potential Conflict of Interest}

D.J. and H.S-K are employees of CelleBrain Ltd. H.S-K. is a founder of CelleBrain Ltd.

\section{Supplementary Materials}

Supplementary data including one table and two figures can be found with this article online at http://pdf.medrang.co.kr/paper/pdf/IJSC/IJSC-13-s19111.pdf.

\section{References}

1. Benjamin EJ, Virani SS, Callaway CW, Chamberlain AM, Chang AR, Cheng S, Chiuve SE, Cushman M, Delling FN, Deo R, de Ferranti SD, Ferguson JF, Fornage M, Gillespie C, Isasi CR, Jiménez MC, Jordan LC, Judd SE, Lackland
D, Lichtman JH, Lisabeth L, Liu S, Longenecker CT, Lutsey PL, Mackey JS, Matchar DB, Matsushita K, Mussolino ME, Nasir K, O'Flaherty M, Palaniappan LP, Pandey A, Pandey DK, Reeves MJ, Ritchey MD, Rodriguez CJ, Roth GA, Rosamond WD, Sampson UKA, Satou GM, Shah SH, Spartano NL, Tirschwell DL, Tsao CW, Voeks JH, Willey JZ, Wilkins JT, Wu JH, Alger HM, Wong SS, Muntner P; American Heart Association Council on Epidemiology and Prevention Statistics Committee and Stroke Statistics Subcommittee. Heart disease and stroke statistics-2018 update: a report from the American Heart Association. Circulation 2018;137:e67-e492

2. Goyal M, Menon BK, van Zwam WH, Dippel DW, Mitchell PJ, Demchuk AM, Dávalos A, Majoie CB, van der Lugt A, de Miquel MA, Donnan GA, Roos YB, Bonafe A, Jahan R, Diener HC, van den Berg LA, Levy EI, Berkhemer OA, Pereira VM, Rempel J, Millán M, Davis SM, Roy D, Thornton J, Román LS, Ribó M, Beumer D, Stouch B, Brown S, Campbell BC, van Oostenbrugge RJ, Saver JL, Hill MD, Jovin TG; HERMES collaborators. Endovascular thrombectomy after large-vessel ischaemic stroke: a meta-analysis of individual patient data from five randomised trials. Lancet 2016;387:1723-1731

3. Marto JP, Lambrou D, Eskandari A, Nannoni S, Strambo D, Saliou G, Maeder P, Sirimarco G, Michel P. Associated factors and long-term prognosis of 24-hour worsening of arterial patency after ischemic stroke. Stroke 2019;50:27522760

4. Yoon JS, Jo D, Lee HS, Yoo SW, Lee TY, Hwang WS, et al. Spatiotemporal protein atlas of cell death-related molecules in the rat MCAO stroke model. Exp Neurobiol 2018;27:287-98

5. GBD 2016 Neurology Collaborators. Global, regional, and national burden of neurological disorders, 1990-2016: a systematic analysis for the Global Burden of Disease Study 2016. Lancet Neurol 2019;18:459-480

6. Pittenger MF, Mackay AM, Beck SC, Jaiswal RK, Douglas R, Mosca JD, Moorman MA, Simonetti DW, Craig S, Marshak DR. Multilineage potential of adult human mesenchymal stem cells. Science 1999;284:143-147

7. Goldring CE, Duffy PA, Benvenisty N, Andrews PW, Ben-David U, Eakins R, French N, Hanley NA, Kelly L, Kitteringham NR, Kurth J, Ladenheim D, Laverty H, McBlane J, Narayanan G, Patel S, Reinhardt J, Rossi A, Sharpe M, Park BK. Assessing the safety of stem cell therapeutics. Cell Stem Cell 2011;8:618-628

8. Ben-David U, Benvenisty N. The tumorigenicity of human embryonic and induced pluripotent stem cells. Nat Rev Cancer 2011;11:268-277

9. Zomer HD, Vidane AS, Gonçalves NN, Ambrósio CE. Mesenchymal and induced pluripotent stem cells: general insights and clinical perspectives. Stem Cells Cloning 2015;8:125-134

10. Bao X, Wei J, Feng M, Lu S, Li G, Dou W, Ma W, Ma S, An Y, Qin C, Zhao RC, Wang R. Transplantation of human bone marrow-derived mesenchymal stem cells pro- 
motes behavioral recovery and endogenous neurogenesis after cerebral ischemia in rats. Brain Res 2011;1367:103-113

11. Kim SS, Yoo SW, Park TS, Ahn SC, Jeong HS, Kim JW, Chang DY, Cho KG, Kim SU, Huh Y, Lee JE, Lee SY, Lee YD, Suh-Kim H. Neural induction with neurogeninl increases the therapeutic effects of mesenchymal stem cells in the ischemic brain. Stem Cells 2008;26:2217-2228

12. Guan Y, Li X, Yu W, Liang Z, Huang M, Zhao R, Zhao C, Liu Y, Zou H, Hao Y, Chen Z. Intravenous transplantation of mesenchymal stem cells reduces the number of infiltrated Ly6C $(+)$ cells but enhances the proportions positive for BDNF, TNF-1 $\alpha$, and IL- $\beta$ in the infarct cortices of dMCAO rats. Stem Cells Int 2018;2018:9207678

13. Chen J, Li Y, Katakowski M, Chen X, Wang L, Lu D, Lu M, Gautam SC, Chopp M. Intravenous bone marrow stromal cell therapy reduces apoptosis and promotes endogenous cell proliferation after stroke in female rat. J Neurosci Res 2003;73:778-786

14. Sammali E, Alia C, Vegliante G, Colombo V, Giordano N, Pischiutta F, Boncoraglio GB, Barilani M, Lazzari L, Caleo $M$, De Simoni MG, Gaipa G, Citerio G, Zanier ER. Intravenous infusion of human bone marrow mesenchymal stromal cells promotes functional recovery and neuroplasticity after ischemic stroke in mice. Sci Rep 2017;7: 6962

15. Li Y, Chen J, Wang L, Lu M, Chopp M. Treatment of stroke in rat with intracarotid administration of marrow stromal cells. Neurology 2001;56:1666-1672

16. Shen LH, Li Y, Chen J, Zhang J, Vanguri P, Borneman J, Chopp M. Intracarotid transplantation of bone marrow stromal cells increases axon-myelin remodeling after stroke. Neuroscience 2006;137:393-399

17. Ruan GP, Han YB, Wang TH, Xing ZG, Zhu XB, Yao X, Ruan GH, Wang JX, Pang RQ, Cai XM, He J, Zhao J, Pan $\mathrm{XH}$. Comparative study among three different methods of bone marrow mesenchymal stem cell transplantation following cerebral infarction in rats. Neurol Res 2013;35:212220

18. Zhang HL, Xie XF, Xiong YQ, Liu SM, Hu GZ, Cao WF, Wu XM. Comparisons of the therapeutic effects of three different routes of bone marrow mesenchymal stem cell transplantation in cerebral ischemic rats. Brain Res 2018; 1680:143-154

19. Bang OY, Lee JS, Lee PH, Lee G. Autologous mesenchymal stem cell transplantation in stroke patients. Ann Neurol 2005;57:874-882

20. Lee JS, Hong JM, Moon GJ, Lee PH, Ahn YH, Bang OY; STARTING collaborators. A long-term follow-up study of intravenous autologous mesenchymal stem cell transplantation in patients with ischemic stroke. Stem Cells 2010;28: 1099-1106

21. Honmou O, Houkin K, Matsunaga T, Niitsu Y, Ishiai S, Onodera R, Waxman SG, Kocsis JD. Intravenous administration of auto serum-expanded autologous mesenchymal stem cells in stroke. Brain 2011;134(Pt 6):1790-1807

22. Jeong H, Yim HW, Cho YS, Kim YI, Jeong SN, Kim HB, et al. Efficacy and safety of stem cell therapies for patients with stroke: a systematic review and single arm meta-analysis. Int J Stem Cells 2014;7:63-9

23. Hess DC, Wechsler LR, Clark WM, Savitz SI, Ford GA, Chiu D, Yavagal DR, Uchino K, Liebeskind DS, Auchus AP, Sen S, Sila CA, Vest JD, Mays RW. Safety and efficacy of multipotent adult progenitor cells in acute ischaemic stroke (MASTERS): a randomised, double-blind, placebo-controlled, phase 2 trial Lancet Neurol 2017;16:360-368

24. Wang S, Guo L, Ge J, Yu L, Cai T, Tian R, Jiang Y, Zhao $\mathrm{RCh}, \mathrm{Wu}$ Y. Excess integrins cause lung entrapment of mesenchymal stem cells. Stem Cells 2015;33:3315-3326

25. Gholamrezanezhad A, Mirpour S, Bagheri M, Mohamadnejad M, Alimoghaddam K, Abdolahzadeh L, Saghari M, Malekzadeh R. In vivo tracking of 111In-oxine labeled mesenchymal stem cells following infusion in patients with advanced cirrhosis. Nucl Med Biol 2011;38:961-967

26. Shin DH, Kim GH, Lee JS, Joo IS, Suh-Kim H, Kim SS, Hong JM. Comparison of MSC-Neurogeninl administration modality in MCAO rat model. Transl Neurosci 2016;7:164-172

27. Kim SS, Choi JM, Kim JW, Ham DS, Ghil SH, Kim MK, Kim-Kwon Y, Hong SY, Ahn SC, Kim SU, Lee YD, Suh-Kim H. cAMP induces neuronal differentiation of mesenchymal stem cells via activation of extracellular signal-regulated kinase/MAPK. Neuroreport 2005;16:13571361

28. Longa EZ, Weinstein PR, Carlson S, Cummins R. Reversible middle cerebral artery occlusion without craniectomy in rats. Stroke 1989;20:84-91

29. Park SY, Marasini S, Kim GH, Ku T, Choi C, Park MY, et al. A method for generating a mouse model of stroke: evaluation of parameters for blood flow, behavior, and survival [corrected]. Exp Neurobiol 2014;23:104-14

30. Neumann-Haefelin T, Kastrup A, de Crespigny A, Yenari MA, Ringer T, Sun GH, Moseley ME. Serial MRI after transient focal cerebral ischemia in rats: dynamics of tissue injury, blood-brain barrier damage, and edema formation. Stroke 2000;31:1965-1972; discussion 1972-1973

31. Arbab AS, Yocum GT, Rad AM, Khakoo AY, Fellowes V, Read EJ, Frank JA. Labeling of cells with ferumoxidesprotamine sulfate complexes does not inhibit function or differentiation capacity of hematopoietic or mesenchymal stem cells. NMR Biomed 2005;18:553-559

32. Chang DJ, Moon H, Lee YH, Lee N, Lee HJ, Jeon I, et al. In vivo tracking of human neural stem cells following transplantation into a rodent model of ischemic stroke. Int J Stem Cells 2012;5:79-83.

33. Kurtz A. Mesenchymal stem cell delivery routes and fate. Int J Stem Cells 2008;1:1-7

34. Jiang L, Newman M, Saporta S, Chen N, Sanberg C, Sanberg PR, Willing AE. MIP-1alpha and MCP-1 Induce migration of human umbilical cord blood cells in models of stroke. Curr Neurovasc Res 2008;5:118-124

35. Yamagami S, Tamura M, Hayashi M, Endo N, Tanabe H, Katsuura Y, Komoriya K. Differential production of 
MCP-1 and cytokine-induced neutrophil chemoattractant in the ischemic brain after transient focal ischemia in rats. J Leukoc Biol 1999;65:744-749

36. Hill WD, Hess DC, Martin-Studdard A, Carothers JJ, Zheng J, Hale D, Maeda M, Fagan SC, Carroll JE, Conway SJ. SDF-1 (CXCL12) is upregulated in the ischemic penumbra following stroke: association with bone marrow cell homing to injury. J Neuropathol Exp Neurol 2004;63:84-96

37. Zhong Y, Tang Z, Xu R, Lin N, Deng M, Fang H, Lin J, Zhu K, Liu Y, Kang Z. Effect of transplantation route on stem cell migration to fibrotic liver of rats via cellular magnetic resonance imaging. Cytotherapy 2013;15:12661274

38. Janowski M, Lyczek A, Engels C, Xu J, Lukomska B, Bulte
JW, Walczak P. Cell size and velocity of injection are major determinants of the safety of intracarotid stem cell transplantation. J Cereb Blood Flow Metab 2013;33:921-927

39. Yoo SW, Chang DY, Lee HS, Kim GH, Park JS, Ryu BY, Joe EH, Lee YD, Kim SS, Suh-Kim H. Immune following suppression mesenchymal stem cell transplantation in the ischemic brain is mediated by TGF- $\beta$. Neurobiol Dis 2013;58:249-257

40. Steinberg GK, Kondziolka D, Wechsler LR, Lunsford LD, Coburn ML, Billigen JB, Kim AS, Johnson JN, Bates D, King B, Case C, McGrogan M, Yankee EW, Schwartz NE. Clinical outcomes of transplanted modified bone marrow-derived mesenchymal stem cells in stroke: a phase $1 / 2 \mathrm{a}$ study. Stroke 2016;47:1817-1824 